\title{
Research
}

\section{Toward Operationalizing Resilience Concepts in Australian Marine Sectors Coping with Climate Change}

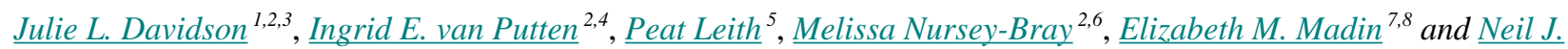
$\underline{\text { Holbrook }}^{2,3}$

\begin{abstract}
We seek to contribute to the scholarship on operationalizing resilience concepts via a working resilience indicator framework. Although it requires further refinement, this practical framework provides a useful baseline for generating awareness and understanding of the complexity and diversity of variables that impinge on resilience. It has potential value for the evaluation, benchmarking, monitoring, and reporting of marine system resilience. The necessity for such a framework is a consequence of the levels of complexity and uncertainty associated with climate change and other global change stressors in marine socialecological systems, and the problems involved in assessing their resilience. There is a need for: (1) methodologies that bring together knowledge from diverse sources and disciplines to investigate the complexity and uncertainty of interactions between climate, ocean, and human systems and (2) frameworks to facilitate the evaluation and monitoring of the social-ecological resilience of marine-dependent sectors. Accordingly, our main objective is to demonstrate the virtues of combining a case study methodology with complex adaptive systems approaches as a means to improve understanding of the multifaceted dynamics of marine sectors experiencing climate change. The resilience indicator framework, the main product of the methodology, is developed using four case studies across key Australian marine biodiversity and resource sectors already experiencing impacts from climate and other global changes. It comprises a set of resilience dimensions with a candidate set of abstract and concrete resilience indicators. Its design ensures an integrated approach to resilience evaluation.
\end{abstract}

Key Words: Australia; climate change impacts; marine sector; resilience assessment; resilience indicator

\section{INTRODUCTION}

Marine systems are recognized as complex adaptive systems that are under considerable stress from a range of anthropogenic impacts (Levin and Lubchenco 2008). In many locations, nonclimate anthropogenic impacts on marine ecosystems from overfishing, bycatch, habitat destruction including from coastal development, and chemical and nutrient pollution are being further exacerbated by climate change (Crowder et al. 2008). Although we consider the consequences of wider global change, our particular focus is on the effects of climate change on marine-dependent industries and associated human populations, because these are expected to be especially affected by climate change (Badjeck et al. 2010, Brander 2010). Indeed, the future of services supplied by marine ecosystems is becoming increasingly uncertain (Gunderson 2003).

Australia's marine systems and biota are exposed to a range of likely impacts from human-induced climate change, including warming ocean temperatures, ocean acidification, sea level rise, changes in nutrient availability, and changes in variability and extremes such as storminess, rainfall intensity and runoff, and associated variation in salinity levels (Poloczanska et al. 2007, 2012). Diverse marine environments are already exhibiting climate change impacts, including extensive coral bleaching along the Great Barrier Reef (GBR; Hoegh-Guldberg et al. 2007, Hughes et al. 2010), poleward range shifting of species (Last et al. 2010), increasing frequency of harmful algal blooms (Hallegraeff 2010), habitat damage from changes in storm frequency and distribution, and ocean acidification (Howard et al. 2009, Poloczanska et al. 2012). All of these have knock-on effects for marine biodiversity and the resilience of marine social-ecological systems (SES; Poloczanska et al. 2012). Ocean warming of Australia's highly productive southeast and southwest marine waters (Holbrook and Bindoff 1997, Pearce and Feng 2007, Ridgway 2007), which are warming faster than $90 \%$ of oceans elsewhere, so-called "hotspots" (Tittensor et al. 2010), has serious implications for dependent marine sectors. As well as these significant climate stressors, marine sectors are subject to a range of nonclimate drivers that often interact with the former and can have a compounding or dampening effect.

As SES, the complex interactions between the social and ecological dimensions of marine sectors are influenced by nonlinearity of feedback effects between the two systems, by associated thresholds, surprises and perverse effects, legacy effects, resilience status, and by spatial, temporal, and organizational variation (Liu et al. 2007). To understand and temper the resulting levels of complexity and uncertainty, a

\footnotetext{
${ }^{1}$ School of Geography and Environmental Studies, University of Tasmania, ${ }^{2}$ Australia's Climate Change Adaptation Research Network for Marine Biodiversity and Resources, ${ }^{3}$ Institute for Marine and Antarctic Studies, University of Tasmania, ${ }^{4}$ CSIRO Wealth from Oceans National Research Flagship, CSIRO Marine and Atmospheric Research, ${ }^{5}$ Tasmanian Institute of Agriculture, University of Tasmania, ${ }^{6}$ Discipline of Geography, Environment and Population, University of Adelaide, ${ }^{7}$ Department of Environmental Sciences, University of Technology Sydney, ${ }^{8}$ Dept. of Biological Sciences, Macquarie University
} 
marine system resilience, vulnerability, and adaptability approach can be beneficial (Young et al. 2006).

Operationalizing resilience in the marine environment is particularly challenging. From an ecological perspective, it is difficult and expensive to develop detailed scientific knowledge about marine systems given that they are large, poorly bounded systems, and often cross-jurisdictional. Consequently, observations of marine biological changes are much fewer than for terrestrial systems (Richardson and Poloczanska 2008). Marine systems often cannot readily be probed by means of experiments at relevant scales (Scheffer 2009), and detecting or predicting key changes like shifts between ocean system states is problematic (deYoung et al. 2004, 2008, Thrush et al. 2009). From a social perspective, it can be difficult to capture the totality of resilience either in measuring the impacts of ecosystem decline on the resilience of marine sectors and institutions, in observing the vulnerability of different resource groups in a meaningful manner (Adger 2000), or in collecting the relevant socioeconomic data (Cinner et al. 2009), especially given the context-specific nature of resilience. A further challenge for operationalization is that, unlike ecosystems, social patterns and structures are conditioned by symbolic construction or meaning, elements of which may divorce human systems from ecological systems and retard responsiveness to ecological signals (Westley 2002).

Additionally, operationalizing resilience is associated with some more general conceptual and practical challenges. The first set of challenges includes developing the commonplace acceptance of SES as complex adaptive systems (Walker and Salt 2006), definitional problems resulting from the ambiguity of the 'resilience' term (Brand and Jax 2007), its dynamic context (Nelson et al. 2007, Bohensky 2008), and constraints on further conceptual development by high levels of system complexity and dynamism (Marshall and Marshall 2007). The second set of challenges involves the practical difficulties of resilience measurement (Carpenter et al. 2005), such as determining which variables to measure (Cumming et al. 2005), developing standard metrics (Cutter et al. 2008), making resilience observable (Nyström et al. 2008, Robinson and Berkes 2010), locating and finding measures for thresholds (Walker and Meyers 2004, Eakin and Luers 2006), acquiring sufficient data (Malone and Brenkert 2008), and measuring resilience in a context of multiple fast- and slowmoving drivers of change (Nelson et al. 2007).

For our purposes, resilience operationalization is the practical application of resilience concepts in decision making and planning. Operationalization entails making resilience concepts useful and useable beyond their theoretical context to policy makers and managers in marine SES and using the lessons from such application to further inform resilience's conceptual and practical development.
As a contribution to the literature on operationalizing resilience, we develop and present a resilience indicator framework, based on investigations of the system dynamics of four Australian marine sectors experiencing impacts from climate and other sources of global change. We propose an approach to resilience diagnosis that reflects the multidimensionality and complexity of marine SES. We use four case studies to develop a set of critical resilience dimensions to underpin our framework.

\section{METHODOLOGIES FOR A RESILIENCE INDICATOR FRAMEWORK}

\section{Resilience and complex adaptive systems}

The theoretical grounding for this study is in the approach to SES proposed by the Resilience Alliance (2007) and its associates. This work owes much to ecologists such as Gunderson and Holling (2002; see also Holling 2001) and the concepts they propose for understanding complex SES, such as the adaptive cycle and panarchy. A key tenet of this theory is that change rather than equilibrium is the normal state of complex adaptive systems. As a result of enhanced interconnectedness between social and ecological systems, it is becoming clearer that change is increasingly predictable, whether it be gradual or unexpected change (Nelson et al. 2007). In marine environments subject to climate change and variability, such changes are a function of the complex nonlinear feedbacks among human production, ocean, and climate systems. The operation of feedbacks can generate unexpected disturbances and outcomes, which, in turn, create an environment of uncertainty for marine managers. One of the virtues of a resilience approach is that it opens up the possibility of operating in this "zone of uncertainty" (Bourdieu 1999).

If we follow Bourdieu's line of reasoning, we understand this zone to be one that allows for transformative spaces to be created in which the ways of behaving and acting that are taken for granted can be unsettled and interrogated so that novel responses to complex problems can emerge and be tested. Although predictions cannot be made with confidence, causes may be unclear, and contradictory conditions are evident, operating in the zone of uncertainty can enable the sort of reflexivity and adaptive practice that support rapid reevaluation of dominant conceptualizations of conditions. The zone of uncertainty is paralleled in complex adaptive systems by the 'back loop' of the adaptive cycle in which levels of system resilience are low, and the system is open to external influences, novelty, innovation, experimentation, learning (Holling 2001), and 'windows of opportunity' (Olsson et al. 2004).

The potential of the back loop is complemented by the understanding that complex adaptive systems are capable of operating in multiple states, effectively allowing for the 
possibility of changing the system state. An associated concern for complex adaptive systems is avoiding transformation into a qualitatively different and undesirable state as a result of disturbance. This is a function of their resilience, which describes the amount of change they can undergo and retain the same controls on structure and function, their capacity for self-organization, and their ability to build capacity to learn and adapt (Walker et al. 2002, Folke 2006, Marshall and Marshall 2007; see also http://www.resalliance.org/index. php/resilience). Resilience analysis therefore needs to account for those slowly changing variables on which resilience depends, the key feedbacks operating among the different systems, nearness to thresholds that might carry the system into an undesirable state, and the capacity for reorganization in the face of both gradual and transformative change.

\section{A case study approach to operationalizing resilience}

Empirical robustness is achieved by using case examples of sectors currently dealing with climate change impacts. The particular case studies discussed here are instrumental case studies (Stake 2000), selected to provide insight into the interactions and interdependencies between linked social and ecological systems threatened by novel climate change impacts. The cases are also of the extreme and critical kind (Flyvberg 2006) because they comprise different types of marine-dependent sectors already dealing with climate change effects, although they utilize marine resources in different ways. As extreme cases, they exemplify instances in which climate change impacts are particularly problematic, e.g., the effects of species shifting their ranges in response to climateinduced changes in ocean circulation, impacts of ocean warming on fisheries and aquaculture in a global warming hotspot, and the impacts of extensive coral bleaching on marine tourism in the GBR. As critical and extreme cases, it was anticipated they would provide both the maximum amount of information and understanding about the dynamics of four different SES and therefore generate a valid set of data as the basis for an indicator framework.

The main purpose in combining case study and complex adaptive systems approaches to appraising marine sector resilience was to ensure that due consideration was given to the complexity, uncertainty, and multidimensionality that is inherent in such an enterprise in the context of global climate change, especially in marine-dependent sectors.

The four studies of marine sector resilience were undertaken in 2009/10 under the auspices of Australia's Climate Change Adaptation Research Network for Marine Biodiversity and Resources, one of the National Climate Change Adaptation Research Facility's eight national adaptation networks. The case studies, i.e., range shifting of marine species in response to ocean warming, the Tasmanian commercial rock lobster (Jasus edwardsii) fishery, oyster aquaculture in southeastern Australia, and tourism in the GBR were selected on the basis of climate change impacts of current concern, researcher expertise, and data availability. The sectoral cases were approached from a disciplinary perspective first, focusing initially on ecological (species range shifting), economic (rock lobster), institutional (oyster aquaculture), social (GBR tourism) resilience perspectives. Key aspects of the case sectors are outlined in Table 1.

Conclusions about the resilience of each case study system cannot easily be drawn at this stage. The evidence for rangeshifting species is still emerging; however, some shifts will have dramatic repercussions for receiving ecosystems whereas others will be viewed as benign or even beneficial from a human perspective (Madin et al. 2012). Those in the former category may possibly cause regime shifts as is happening with the invasion of the urchin species, Centrostephanus rogersii, which is damaging the resilience of rocky reef ecosystems and dependent fisheries along Tasmania's east coast (Johnson et al. 2011). The Tasmanian rock lobster industry is rated as having high economic resilience in relation to its governance and management institutions and for its fleet capacity; however, the sector is vulnerable in terms of fuel costs, supply chain components such as information flow and innovation, and financial security (Pecl et al. 2009, van Putten and Gardner 2010).

Oyster aquaculture's vulnerabilities include water quality impacts resulting from catchment activities, absence of integrated terrestrial-marine governance, and lack of understanding of the biophysical basis of the industry (Leith and Haward 2010). However, emergence of collaborative management approaches between government and growers and improvements in oyster species' resistance to disease, maintenance of productive environmental conditions, and management improvements will contribute to sector resilience. The New South Wales industry is more vulnerable to climate change impacts, through outbreaks of disease and flooding, than the South Australian and Tasmanian segments. Great Barrier Reef tourism is especially vulnerable to climate change impacts through increased risk of vector-borne disease, increased intensity of natural hazards, e.g., cyclones, and reduced biodiversity (Marshall et al. 2009). However, the existence of multilevel, collaborative governance arrangements and interactions among scientists, environmental managers, tourism operators, fishing industries, and the broader community provides a high level of institutional and social resilience.

As a prelude to the presentation of the resilience indicator framework, we discuss the challenges for resilience frameworks, establish a rationale for the use of frameworks in SES studies, discuss the role that indicators can play in operationalizing resilience concepts, and consider precursors for resilience indicators. 
Table 1. Case study descriptions: system characteristics, external drivers, and observed climate change impacts.

\begin{tabular}{ll}
\hline \hline $\begin{array}{l}\text { Case } \\
\text { Study }\end{array}$ & Key System Characteristics \\
\hline $\begin{array}{l}\text { Marine } \\
\text { species } \\
\text { range } \\
\text { expansion }\end{array}$ & $\begin{array}{l}\text { Marine species' range boundaries } \\
\text { are often determined in part by } \\
\text { habitat characteristics, both } \\
\text { physical, e.g., temperature, } \\
\text { substrate, and biological, e.g., } \\
\text { competition, predation }\end{array}$ \\
& \\
& \\
& $\begin{array}{l}\text { Changes in one or more of these } \\
\text { range boundary determinants may } \\
\text { cause a species range edge to shift } \\
\text { Climate change is likely to lead to } \\
\text { changes in one or more of these } \\
\text { determinants for some marine } \\
\text { species }\end{array}$
\end{tabular}

The evidence is mounting that such range shifts are occurring as a result, either directly or indirectly, of climate change

Southern One of Tasmania's most valuable rock

lobster resources, with the industry worth over A $\$ 65 \mathrm{~m}$ 2011-12 (but below

(Jasus

edwardsii)

industry

Dependent on rocky reef/ macroalgal (kelp) habitat along the coastline

Declining state-wide stock abundance (mainly last 5 years)

Product value differentiation (higher value red lobster caught in north - lower value paler lobster caught in colder southern waters) Reducing fisher participation since Individual Transferable Quota (ITQ) introduction (efficiency gains); around 312 licenses but 200 commercial fishers Increasing investor ITQ ownership
Main Climate Stressors/Drivers Main Nonclimate Stressors/ Observed Climate Change Impacts Drivers temperatures (SSTs) via strengthening of the East Australian Current (EAC), aiding larval transport and bringing tropical water further south leading to changes in productivity
Increasing sea surface
Habitat destruction from growth of coastal population and poorly planned coastal development, destructive fishing practices, shipping accidents, and boat anchorages
Strengthening of the EAC (20\% since 1960), causing changes in physical, chemical, and biological properties of temperate waters (Malcolm et al. 2011). Southward EAC extension has caused silicate concentrations to decline off eastern Tasmania (Thompson et al. 2009)

Nonclimate-related changes in oceanographic conditions

Fishing-mediated changes in competitor and predator assemblages

Over $2.0^{\circ} \mathrm{C}$ increase in SST (east coast Tasmania 1944-2005) and declines in precipitation via a longterm drying trend have led to increasing salinity and therefore changes in productivity (declines of $8 \%$ per year in chlorophyll $a$ concentrations, 1944-2005; Thompson et al. 2009)

Temperature increases have contributed to a decline in larval lobster settlement in eastern Tasmania over the last 15 years

Southward extension of the warm EAC (350km since 1960s)
Increasing numbers of urchins (Centrostephanus rodgersii) invading from warmer New South Tasmania (mainly last 5 years) Wales (NSW) waters assisted by EAC extension

Kelp beds (rock lobster habitat) contracting due to urchin grazing

Increasing octopus (Octopus tetricus) sightings, a likely predator of rock lobster (www. redmap.org.au)

Increasing sightings of NSW rock Urchin barrens now cover 50\% of lobster species (Sagmariasus verreauxi; www.redmap.org.au)

Changing fishery demographic (fewer young fishers entering because of alternative higherearning opportunities elsewhere)

Changing quota ownership characteristics are increasing variable fishing cost for lease quota fishers
Relative geographic redistribution of fishing effort (declined by $50 \%$ in northern waters and doubled in cooler southern waters, 1970-2009; Pecl et al. 2009) Interaction between increasing fishing pressure on high value red lobsters (Green et al. 2010), opportunities for rock lobster translocation, and climate driven temperature increases. some northeast Tasmania rocky reefs since arriving in the late 1970s

Increasing octopus catch and octopus predation of lobster in pots

Reduced Total Allowable Commercial Catch (TACC; 1523 tonnes in 2008/09 to 1193 tonnes for 2012/13). Actual catch declined from 2200 to 1500 tonnes, between 1985 and 2008 (Linnane et al. 2010) 
Aging fisher demographic

Oyster The value of the Australian oyster Warming SSTs; air temperature; aquaculture industry is estimated around $\mathrm{A} \$ 120 \mathrm{~m}$ in 2011

Distributed aquaculture sector spread across bays and estuaries of NSW, South Australia, and Tasmania

POs and SROs are main species

Numerous disease threats to both species

Numerous land use and surface runoff risks in estuarine systems

Mostly small, family-run businesses

Access to water based on leasehold; arrangements vary slightly between states

Great

Barrier

Reef

marine

tourism upstream management and

Reef tourism contributed around A \$5.1 billion to the Australian economy in 2006 existing stressors associated with

Diversity of small-medium

businesses (retail, accommodation, and tour based) Resilient to change (Fenton et al. 2007)

Spatially differentiated operations across inner and outer coral reefs and islands zonal wind change; extreme rainfall events; sea-level rise limiting use of/access to land bases

Likely to be most substantial in estuarine regions where rainfall changes can exacerbate predevelopment

Likely to be caused by complex synergistic interactions between multiple climatic and other drivers rather than a single cause

Increasing fishing costs due to greater search time and farther travel

Land use in catchments affecting runoff and water quality

Disease outbreaks, which may be linked to climate drivers, such as herpes viruses and vibrios in Pacific oysters (Crassostrea gigas; POs), and the complex and fatal pathological conditions known as QX and winter mortality in Sydney rock oysters (Saccostrea glomerata; SROs).

Issues relating to social license affect the legitimacy of the sector and thus the levels of political support

Energy costs of transport and cooling, related to distance to markets

Reef based tourism is vulnerable to climate change impacts: sea level rise, increased water and air temperatures, increased storm/ cyclone frequency and severity, ocean acidification, increased windspeed, changed rainfall and runoff, cloud cover affecting visibility, and changes in El Niño Southern Oscillation (Coghlan and Prideaux 2009, Wilson and Turton 2010).
Substantial falls in visitor numbers are expected if environmental conditions, e.g., water quality, are degraded significant implications for regional annual income (Huybers and Bennett 2000). (De'ath and Fabricius 2008) with
Increased flood frequency in northern NSW is causing acidification of estuarine waters and resulting in higher estuary closure rates, i.e., farmers are unable to sell their stock more often (Dove and Sammut 2007)

Increasing water temperature in northern NSW has been linked to increased risk and outbreaks of QX; aquaculture here has not recovered from QX outbreaks in the 1970s (Nell 2007)
Sea and air temperatures are increasing; there is observed sea level rise, ocean acidification and more intense storms and more frequent rainfall (Poloczanska et al. 2012)
Global economic activity and other factors influencing businesses' profitability
Coral bleaching events on nearshore reefs have increased in frequency and severity since 1990 (Thompson and Dolman 2010) 


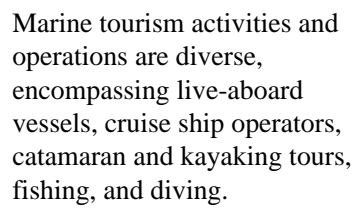

Marine tourism activities and operations are diverse, encompassing live-aboard vessels, cruise ship operators, catamaran and kayaking tours, fishing, and diving.

Reef bleaching influences the number of visitors (Oxford Economics 2009).

Contributes to a growing hospitality industry of resort-style accommodations and restaurant services.
Recreational and tourism services are strongly related to coral reef biodiversity, coral cover, and water clarity (Wielgus et al. 2004).
Existence of alternative reef destinations and competition with and economic viability of other iconic tourist attractions, such as North Queensland's Wet Tropics

Rapid coastal population growth (Great Barrier Reef Marine Park Authority 2009).
Long lived corals are calcifying $15 \%$ less than prior to 1990 (Hoegh-Guldberg et al. 2007, De'ath et al. 2009).

\section{Challenges for resilience frameworks}

One of the challenges of resilience approaches to SES is to integrate understanding from multiple disciplines, methods, and perspectives (Berkes 2007). Indeed, the study of complex systems necessitates interdisciplinarity because of their multifaceted dimensions, limited predictability, and dynamism (Newell 2001). A further challenge is to enable improved management of uncertainty and surprise. Currently, uncertainty is most often handled within a risk management framework. In highly dynamic contexts, uncertainty can be managed more effectively using an emergent/contingent framework that explicitly deals with surprise. This is necessary because the kinds of events or outcomes associated with the nonlinear feedbacks that characterize complex interactions between the climate, ocean, and human production systems are concerned with what van der Heijden (1996) refers to as "structural uncertainties," i.e., possible events for which there is little or no evidence to judge the likelihood of an outcome, and "unknowables" or unimaginable events.

Consequently, some of the key functions of a resilience indicator framework should be to support ways of operating in the zone of uncertainty, facilitate identification of windows of opportunity and potential transformative spaces, and inform capacity building to better prepare for and respond to surprise.

\section{Operationalizing resilience through indicator frameworks}

Although resilience indicator frameworks are in their infancy, scholarship around the use of sustainability and environmental indicator frameworks hints at how indicators could help in operationalizing resilience. From a policy perspective, indicators can enhance the overall understanding of resilience as a concept because the resulting reflection of ongoing assessments can lead to the gradual incorporation of resilience goals and standards into policies and organizations, the socalled enlightenment effect (Gudmundsson 2003). Indicators are valuable in providing information on complex issues in a way that is accessible to decision makers (Niemeijer and de Groot 2008). They can also stimulate change in stakeholders and systems through ongoing processes of negotiation and learning (Reed et al. 2006), with the eventual and desirable outcome of such processes being legitimization of a resilience orientation (Cabell and Oelofse 2012).

From the perspective of dealing effectively with change, indicators perform several functions. First, they can be used to establish baselines and to determine the direction of change in relation to a particular condition of resilience such as a threshold. In monitoring change, thresholds, targets, or baselines, beyond which problems become critical, serve to trigger remedial action (Reed et al. 2006). Information from monitoring indicators can be used as the basis for adaptive management strategies that help stakeholders adapt to and manage change. Lastly, indicators can enhance processes of social learning through stakeholder participation in indicator development processes (Pretty 1995).

From a resilience perspective, the sustainability indicators literature is deficient in that, with few exceptions (for example, Grosskurth and Rotmans 2007), it has so far not captured the broader dynamics of systems, and these are critical to both sustainability and resilience. Although monitoring indicators can adequately support incremental adaptive change, a different class of indicators is required in uncertain contexts to capture the complexities of system dynamics. These indicators could be developed through futures planning techniques such as scenario analysis (Haward et al. 2013), thus facilitating the consideration of potential windows of opportunity and suggesting areas to build capacity to better respond to surprise. With respect to the latter, resilience indicators should be significant sources of social-ecological learning, identified as a critical element of resilience building and for coping with uncertainty and surprise (Kofinas and Chapin 2009).

Although aware that the selection of indicators ultimately depends on the research question being asked or the objectives of a particular study, we sought to identify a set of indicators that would be useful in a general sense in the diagnosis and monitoring of marine sector resilience. The decision to 
develop indicators as measures of resilience rather than resilience metrics per se is supported by the opinions of others that the value of resilience thinking is more likely to be realized in industry sectors and systems by identifying general rules of thumb that can guide sectors toward a resilience orientation (Bennett et al. 2005, Carpenter et al. 2005, Darnhofer et al. 2010, Cabell and Oelofse 2012). Consequently, we were not concerned at this stage to adhere closely to accepted ideals of data availability, measurability, and cost effectiveness in indicator selection.

Presentation of indicators in a framework format is supported by Walmsley (2002) who suggests that the use of frameworks for sustainability indicators is crucial to identifying, summarizing, and reporting on key issues because it enables the logical grouping of information and thus the promotion of indicator interpretation and integration. Frameworks also help in the identification of data collection needs and gaps. Similarly, Ostrom (2011:8) advocates the use of frameworks in diagnostic work because frameworks establish the "elements and general relationships among these elements that one needs to consider for ... analysis and they organize diagnostic and prescriptive enquiry. They attempt to identify the universal elements that any theory relevant to the same kind of phenomena needs to include." A key purpose of the framework presented here is to ensure that important aspects of resilience concerns are identified and considered in studying and managing marine sector resilience.

\section{The process of resilience indicator framework development}

The framework has three main components: a set of critical resilience dimensions, a capitals or assets framework to organize the indicators, and indicator subsets, both abstract and concrete. Following initial assessment of the respective social, economic, institutional, and ecological resilience foci for each case study, the lead researchers overseeing each case study combined their expertise at a workshop held in January 2011, where they drew on their links with marine researchers, policy makers, and managers to provide a more comprehensive, interdisciplinary assessment of marine system resilience dimensions across the four sectoral case studies. The methodology was guided by the systems dynamics approach developed by the Resilience Alliance (2007) and informed by Bennett et al.'s (2005) work on resilience surrogates. The researchers identified a set of eight resilience dimensions that could be applied to sectors to describe current and potential resilience (Table 2). Thus the resilience dimensions set, grounded in a rigorous interdisciplinary process, provided the ideal basis for a comprehensive indicator framework.

The case information was synthesized into a matrix composed of the eight resilience dimensions and five asset classes. The latter, which encompass a range of livelihood resources, i.e., ecological, social/human, economic/financial, political/ institutional, and infrastructural/technological (physical) assets, adapted from Scoones' (1998) sustainable livelihoods framework, are used to elaborate the resilience dimensions (Table 3). Livelihood perspectives have been shown to be useful in complex, highly dynamic development contexts (Scoones 2009). Applying this framework helped to ensure the balanced treatment of all relevant system components, although the addition of political and institutional assets, in particular, secured the inclusion of governance and power factors.

To formulate the indicator component of the framework, exemplars were extracted for each resilience dimension and for as many asset classes as possible from the case study data (refers to columns 2 and 3 in Table 4). The exemplars represent abstract indicators of sector resilience, which, although useful at a conceptual level, are not usually sufficiently concrete as the basis for data collection (Niemeijer and de Groot 2008). In column 4, we suggest potential concrete indicators for each abstract indicator and provide a rationale for each indicator in column 5 .

\section{ANALYSIS AND DISCUSSION}

Evaluation of the resilience indicator framework's utility as a first step in system resilience appraisal requires some consideration of its capacities for benchmarking, monitoring, evaluating, and reporting on SES resilience. In part, this capacity is dependent on the comprehensiveness of resiliencerelevant content, and, in part, on the ease with which the framework can be operationalized. Operationalization will be influenced by (1) the development of appropriate resilience metrics, currently limited by data availability, and (2) the framework's further refinement. In our integrated approach to SES resilience, we addressed a range of resilience preconditions, including opportunities for social-ecological learning, preparedness for surprise, ability to cope with uncertainty, ways of dealing with complexity, and the presence of transformative spaces and windows of opportunity.

Social-ecological or resilience learning is catered for by ensuring multiple stakeholder perspectives and knowledge systems are incorporated in problem solving. This capacity for systematic learning through dialogue, deliberation, and meaningful social interaction to enhance long-term sustainability and resilience under uncertain conditions is determined by indicators for trust building and purposeful strategies to enhance social capital (Béné et al. 2011). Social capital is also a crucial ingredient in the necessary collaboration of industry, managers, policy makers, and other stakeholders to effect transformative action.

Preparedness for surprise and capacity to cope with uncertainty needs a substantial monitoring program, although there will always be unforeseeable events. In turn, monitoring aids the social learning needed in responding to change. Other 
Table 2. Resilience dimensions, justification, and illustrative examples.

\begin{tabular}{ll}
\hline \hline $\begin{array}{l}\text { Resilience } \\
\text { Dimension }\end{array}$ & Justification \\
\hline $\begin{array}{l}\text { Factors } \\
\text { undermining }\end{array}$ & $\begin{array}{l}\text { Awareness of factors contributing to social-ecological } \\
\text { system (SES) vulnerability is needed to manage their } \\
\text { resilience }\end{array}$ \\
capacity to produce ecosystem services.
\end{tabular}

Key slow Slow variables are controlling variables that are buffered variables affecting by stabilizing feedbacks and determine the ability of a resilience system to stay in a particular system state (Chapin et al. 2009).

Key fast variables Fast variables are those operating at shorter temporal and affecting smaller spatial scales that can cause changes in slow resilience variables operating at longer time scales.

Example

Key feedbacks Feedbacks between biotic and abiotic components of marine systems, and climate and socioeconomic systems can act synergistically to drive SES into less desirable states (Harley et al. 2006).

Likelihood of crossing thresholds

Response to uncertainty and surprise

Identifying the likelihood of a system crossing a threshold into a less desirable state will indicate its resilience and what should be done to strengthen adaptive capacity and increase sectors' or systems' ability to move toward institutions/practices that allow sectors to learn and innovate (Berkes 2007).

The ability of a society to live with surprise and uncertainty is a key factor in building resilience (Folke et al. 2003, Berkes 2007).

Openness to resilience ideas

Openness to resilience ideas acts as a proxy for SES preparedness to adapt to change. This is especially relevant given increasing evidence that future changes may be sudden and disruptive.

Potential to SES resilience is largely dependent on ability to reorganize reorganize in the event of disturbance. Reorganizati be directed to a degree if critical capacities are maintaine (Folke et al. 2003).
Poor water quality caused by runoff from adjacent catchments is a significant stressor of North Queensland coral reefs (Fabricius 2011). Management authorities established the Reef Rescue program to improve agricultural practices and monitor water quality (Eberhard Consulting 2011).

The resilience of coral reefs to cyclones, warming sea surface temperatures, and anthropogenic stressors determines whether or not reefs shift into less productive algal-dominated systems (Hughes et al. 2007).

Fishing effort increases through technological intensification in conjunction with recent climate change-induced oceanographic changes contribute to localized rock lobster (Jasus edwardsii) depletion in southeastern Australia (Linnane et al. 2010).

A synergistic interaction between climate variation (warming waters), fishing pressure (through technological intensification), and long-spined sea urchin (Centrostephanus rodgersii) predation on kelp beds affects abalone and lobster stocks (Last et al. 2010) and can be a first step transformation to a new SES state. The recently arrived urchins can now be harvested, partially replacing declining abalone and rock lobster fisheries and also redirecting diving effort and labor. Coastal communities and their fishing fleets may consequently change in composition and size.

Overgrazing of Tasmania's productive east coast kelp forests by the rangeextending long-spined sea urchin from warm temperate waters is contributing to a catastrophic regime shift (Ling et al. 2009). Restocking of rocky reefs with large lobsters (urchin predators) is intended to counter the effects of their earlier overfishing, which facilitated successful urchin invasion in the first place.

Successive major cyclones and coral bleaching events along North Queensland coral reefs have put many coastal communities at risk of permanently losing the ability to attract tourists. In recognition of future change, tourism operators have implemented eco-efficiency measures such as risk management, energy reduction, and building climate change into business plans (Zeppel 2012).

The Fisheries Research and Development Corporation (2010) is encouraging Australian fisheries to adapt to climate change through providing research support (Hamon et al. 2013, Pecl and Hobday 2011) and fostering initiatives, such as conducting vulnerability assessments. 'No take' areas on coral reefs help to maintain biodiversity (ecological memory) which is crucial to regeneration after disturbance by tropical cyclones (Mumby et al. 2006). indicators of enhanced response capacity under conditions of surprise and uncertainty comprise perceptions of risk (Marshall and Marshall 2007), infrastructure planning and flexibility, availability of a diverse range of responses, ongoing learning, planning for extreme events, and futures planning.

Indicators that account for complexity include planning for extreme events, openness to innovation, response diversity, resilience building, collaborative management and governance that can help to create learning (Booher and Innes 2010), selforganizing processes, diversity of risk responses, trends in economic diversification, adaptive management, and innovative approaches to environmental management. It is expected that guidance from these indicators would help to manage complexity.

Prospects for transformational change are indicated by the presence of transformative spaces in which accepted practices can be unsettled and interrogated. These could be evident where there are processes of critical reflection in place, such as in shadow networks, i.e., networks that operate outside the mainstream testing new or innovative ideas, practices, and approaches (Olsson et al. 2006). However, any threat to the current stability regime is also a potential site for transformation, e.g., natural disasters, declines in keystone species, a drop in fishing effort, catch trophic changes, stock collapses or declines, pest invasions, and economic crises, 
Table 3. Description of asset classes relevant to marine sectors (adapted in part from Scoones 1998).

\begin{tabular}{ll}
\hline \hline Asset Classes & Description \\
\hline Ecological & $\begin{array}{l}\text { Natural resource stocks (soil, water, air, genetic resources) and environmental services (carbon and hydrological } \\
\text { cycles, pollution sinks, etc.) from which useful resource flows and services are derived }\end{array}$ \\
Social/human & $\begin{array}{l}\text { Social resources (relationships of trust, connectedness, reciprocity, and exchanges) gained through membership } \\
\text { of collective networks and individual endowments (skills, knowledge, information, health, ability to work) that } \\
\text { facilitate access to social resources }\end{array}$ \\
Economic/financial & $\begin{array}{l}\text { Economic conditions (profitability, economic activity, and market conditions) that influence business viability } \\
\text { and financial resources (savings, access to credit, and liquid assets readily converted to goods, remittances, and } \\
\text { pensions) essential for a viable business }\end{array}$ \\
Institutional/political & Formal and informal instruments for decision making and the influences applied in decision making \\
Infrastructural/technological & $\begin{array}{l}\text { Infrastructure, technology, tools, and equipment needed for communications and to produce food, commodities, } \\
\text { and services. }\end{array}$ \\
\hline
\end{tabular}

such as transport stoppages or declining economic returns. These may open windows of opportunity to contemplate new solutions, practice changes, and so on.

Although unexpected events may open windows of opportunity on an irregular basis, a more important question is: Can the framework facilitate the purposeful creation of windows of opportunity? Westley (2002) argues that, to allow a policy window to open, all the relevant actors and organizations at all levels have to create the right links, at the right time, and around the right issues. The fora of operators, managers, and scientists conducted within the aquaculture and fishing industries have the potential to create appropriate alignments of actors, organizations, and issues at crucial times but policy entrepreneurs need to provide leadership and generate the political will to push in new directions (Olsson et al. 2004). This reliance on the serendipitous alignment of the appropriate factors points to the importance of systematically prefiguring institutional reform to be prepared for brief windows of opportunity (Young 2010). Such fora must purposively incorporate processes of critical reflection on current practice and industry or sector direction. This aspect is reflected in the indicator requiring the installation of processes for critical reflection to reevaluate norms, values, rules, and practices.

Lastly, for transformation to be initiated, the system must be open to external influences, and have capacities for novelty, innovation, and learning. The relevant indicators that represent these values include maintenance of species diversity from an ecological perspective, flexibility of location or equipment from a marine sector perspective, innovative approaches to environmental management, potential for consumer preference revision, individuals' preparedness for change (Marshall et al. 2007, Marshall 2010), educational attainment, existence of multilevel networks, and stakeholder inclusiveness.

\section{CONCLUSIONS AND FUTURE POTENTIAL}

We conceptualized resilience as a complex and dynamic multidimensional model of change in SES. We anchored the resilience indicators framework in a case study methodology and a systems dynamics approach for the purpose of capturing this complexity. Key resilience dimensions and a related set of resilience indicators applicable to marine sectors experiencing climate change were identified. The comprehensiveness of the indicator framework relied on taking an interdisciplinary approach to data collection and a suitable framework to ensure that all relevant elements were considered. Although the method of indicator development is readily replicable, it should be understood that a different group of research participants may identify a different indicator set. Although the framework requires further refinement, we have been able to demonstrate through the methodology that it is possible to capture the complexity and variety of variables impinging on marine sector resilience.

Although the framework is not yet ready for immediate implementation, it provides a baseline that can be used for discussion and to focus attention on the diversity and complexity of factors influencing resilience. The indicators act as prompts for the kinds of variables that should be considered. They suggest negative factors or constraints on resilience that should be taken into account and positive or negative trends that may influence resilience-building efforts. They include reminders to allow for the unexpected and for the importance of having adequate responses to deal with uncertainty. They provide examples of critical feedback signals and possible signs of impending thresholds. Lastly, they suggest potential demonstrations of resilience action and the kinds of capacities and precursors required to respond to system change.

The immediate practical value of the indicator framework resides in its potential use in: 
Table 4. Resilience indicators framework.

\begin{tabular}{|c|c|c|c|c|}
\hline $\begin{array}{l}\text { Resilience } \\
\text { Dimensions }\end{array}$ & $\begin{array}{l}\text { Asset } \\
\text { Class }^{\dagger}\end{array}$ & $\begin{array}{l}\text { Examples of Resilience } \\
\text { Factors (Abstract Indicators) }\end{array}$ & $\begin{array}{l}\text { Suggestions for Concrete } \\
\text { Resilience Indicators }\end{array}$ & Rationale/Relevance \\
\hline \multirow{12}{*}{$\begin{array}{l}\text {. Factors } \\
\text { undermining } \\
\text { resilience }\end{array}$} & \multirow[t]{5}{*}{$\mathrm{Ec}$} & $\begin{array}{l}\text { Nonavailability of suitable } \\
\text { habitat }\end{array}$ & Habitat integrity index & $\begin{array}{l}\text { Ecosystems with degraded habitat are less able to support } \\
\text { diverse ecological and social communities }\end{array}$ \\
\hline & & & Water quality index & \\
\hline & & Absence of refugia & Availability of refuge habitat & $\begin{array}{l}\text { Habitat-specific species require suitable habitat and ecological } \\
\text { conditions to migrate to in the event of disturbance }\end{array}$ \\
\hline & & $\begin{array}{l}\text { Vulnerability to extreme } \\
\text { events }\end{array}$ & $\begin{array}{l}\text { Recovery time of species after } \\
\text { extreme events }\end{array}$ & $\begin{array}{l}\text { Some species are more vulnerable to disturbances than others, e. } \\
\text { g., branching versus massive corals. Recovery after extreme } \\
\text { events, e.g., cyclones, may be further hindered by reduced water } \\
\text { quality and ocean acidification }\end{array}$ \\
\hline & & Environmental degradation & $\begin{array}{l}\text { Loss of key habitat, e.g., } \\
\text { seagrass, coral reefs, } \\
\text { mangroves, kelp forest }\end{array}$ & $\begin{array}{l}\text { Many of the key habitats that species depend on for food, } \\
\text { security, and reproduction are being lost as a result of human } \\
\text { activities }\end{array}$ \\
\hline & S & Attitudinal change & $\begin{array}{l}\text { Changes in consumer } \\
\text { preferences }\end{array}$ & $\begin{array}{l}\text { Growth in consumer preferences for particular seafoods or } \\
\text { tourism destinations may have negative impacts on relevant } \\
\text { species and habitats leading to their degradation or decline, but } \\
\text { also causing economic and social instability }\end{array}$ \\
\hline & \multirow[t]{2}{*}{$\mathrm{E}$} & Profitability & Declines in economic returns & $\begin{array}{l}\text { The necessary buffering capacity provided by profitability is not } \\
\text { available to respond to change or disturbance }\end{array}$ \\
\hline & & Changes in asset value & Declining asset value & $\begin{array}{l}\text { Asset values are related to profitability and thus responsiveness } \\
\text { to change }\end{array}$ \\
\hline & \multirow[t]{3}{*}{ I } & Power relations & Identifiable vested interests & $\begin{array}{l}\text { Vested interests may skew decision making away from the long- } \\
\text { term focus required for resilience planning }\end{array}$ \\
\hline & & Political will & $\begin{array}{l}\text { Absence of political support } \\
\text { for resilience-oriented policy }\end{array}$ & $\begin{array}{l}\text { Political will is needed to reform public institutions to be able to } \\
\text { address the complex problems of resilient social-ecological } \\
\text { systems }\end{array}$ \\
\hline & & International policy decisions & Changes in climate policy & $\begin{array}{l}\text { International decisions on mitigating greenhouse gases may } \\
\text { impact negatively on sectors dependent on export income }\end{array}$ \\
\hline & $\mathrm{P}$ & $\begin{array}{l}\text { Constraints on infrastructure/ } \\
\text { gear flexibility }\end{array}$ & $\begin{array}{l}\text { Inflexibility of infrastructure/ } \\
\text { gear }\end{array}$ & $\begin{array}{l}\text { Inflexibilities in infrastructure and gear may constrain sectors } \\
\text { from adapting to the impacts of climate change }\end{array}$ \\
\hline \multirow[t]{5}{*}{$\begin{array}{l}\text { 2. Key slow } \\
\text { variables }\end{array}$} & $\mathrm{Ec}$ & Warming sea temperatures & $\begin{array}{l}\text { Observed changes in sea } \\
\text { temperatures }\end{array}$ & $\begin{array}{l}\text { Warming sea temperatures are having a substantial impact on } \\
\text { ecosystems and will likely affect the future shape of marine- } \\
\text { dependent sectors }\end{array}$ \\
\hline & E & Economic pressures & $\begin{array}{l}\text { Number of people entering or } \\
\text { exiting the industry }\end{array}$ & $\begin{array}{l}\text { When people are constrained by the costs associated with entry } \\
\text { into an industry, replacement of exiting operators is slow leading } \\
\text { to industry stagnation } \\
\text { Stagnation can also be due to retention of nonresilient } \\
\text { individuals who have limited adaptation options }\end{array}$ \\
\hline & \multirow[t]{2}{*}{ I } & Institutional constraints & $\begin{array}{l}\text { Integrated governance/ } \\
\text { management approaches }\end{array}$ & $\begin{array}{l}\text { Governance and management of social-ecological systems is } \\
\text { complex and it is essential that governance bodies and } \\
\text { instruments are connected and coordinated across multiple levels } \\
\text { and that governance is perceived as legitimate }\end{array}$ \\
\hline & & & $\begin{array}{l}\text { Acceptability of rules and } \\
\text { management approaches }\end{array}$ & \\
\hline & $\mathrm{P}$ & Longevity of infrastructure & Replacement of infrastructure & $\begin{array}{l}\text { The longevity of some infrastructure and associated sunk } \\
\text { (irrecoverable) costs may slow adaptation to change }\end{array}$ \\
\hline \multirow[t]{3}{*}{$\begin{array}{l}\text { 3. Key fast } \\
\text { variables }\end{array}$} & \multirow[t]{2}{*}{$\mathrm{Ec}$} & \multirow[t]{2}{*}{$\begin{array}{l}\text { Occurrence and frequency of } \\
\text { natural disasters }\end{array}$} & Frequency of cyclones/storms & $\begin{array}{l}\text { Natural disasters may have unexpected and unpredictable effects } \\
\text { on larger cycles; these effects may be catastrophic or open up } \\
\text { windows of opportunity for management and/or emergence of } \\
\text { novel species }\end{array}$ \\
\hline & & & $\begin{array}{l}\text { Annual catchment runoff } \\
\text { Torrential stream outflow } \\
\text { events }\end{array}$ & \\
\hline & S & $\begin{array}{l}\text { Changes in consumer } \\
\text { preferences }\end{array}$ & $\begin{array}{l}\text { Changes in seafood and } \\
\text { recreation preferences }\end{array}$ & $\begin{array}{l}\text { Changes in preferences for particular seafoods or tourism } \\
\text { experiences may result in further pressures on overloaded } \\
\text { ecosystems thus pushing them toward an irreversible threshold } \\
\text { but also causing economic and social instability }\end{array}$ \\
\hline
\end{tabular}


E Economic variables

Profitability

Equity debt ratios

Market prices

Economic crises

Changes affecting

profitability, e.g., transport

stoppages

I Unexpected policy changes Changes in catch limits
Abundance or areal coverage of invasive species

Habitat changes

Removal of keystone species Changes in keystone species' from climate change affected abundance habitats

E Collapses or declines in key Changes in fishing catch, resource stocks

Increased fishing effort

Overfishing

5. Likelihood of crossing thresholds

6. Response to uncertainty and surprise

S Social threats to particular
Ec Occurrence of species range shifting

Threats to current stability regimes sectors

Perceptions of environmental Declines in tourism activity decline

Public perceptions of marine sectors

E Contributions to greenhouse Greenhouse gas emissions gas emissions Increased economic activity Increased tourism impacts

S Perceptions of risk

Operators/managers accept global climate change science

I Viability of risk response

Diversity of risk responses

Contingency as well as risk management measures are in place

A range of risk responses is available

Political commitment

Adaptive management policy in place

Institutional design

P Infrastructure planning
Long-term monitoring programs in place Replacement program in place
Profitability (including exchange values) and low debt ratios allow more flexibility in business decisions affecting resilience. Producer influence on prices and higher prices increase resilience

Economic crises may lower profitability and therefore buffering capacity over a very short time frame

Changing catch limits may cause relatively rapid responses in the species at issue especially if that species is an ecosystem engineer leading to substantial change in broader ecological and social systems

Pest invasions can signal changes in ecological integrity and result in habitat decline, in turn affecting habitat-dependent species

Keystone species are said to be crucial to maintaining the organization and diversity of their communities so that their decline usually spells the decline of those communities These changes often signal changes in ecosystem health

Policy or market changes may improve incentives to fish and increase pressure on preferred species

Increases in populations of lower trophic level species, e.g., jellyfish

Changes in species composition may signal a range shift, which may fundamentally alter associated ecological communities and fisheries dependent upon these communities

Increasing pest numbers may indicate that the current regime is being destabilized

High entry costs, increased fuel costs, and nonreplacement of aging operators may lead to decline of a sector

Declines in sectors reliant on environmental integrity could signal potential regime shifts in ecosystems. Public perceptions can also significantly influence management outcomes and industry support

Increasing greenhouse gas emissions are associated with ocean warming

Increased marine tourism impacts may result in pressures leading to ecological degradation of favoured ecosystems, e.g., coral reefs

Nonscientists' capacity to anticipate surprise is dependent on acceptance of scientists' analytical assessments of potential surprising climate impacts rather than reliance on direct experience of impacts

A concentration on risk assessment ignores the importance of having the capacity to prepare for surprise

Having a diversity of possible responses to deal with uncertainty and surprise improves the chances of maintaining system resilience

Action to deal with an uncertain future requires political commitment and leadership to transcend short-term concerns that often preoccupy political debate

Being prepared for surprises demands a substantial program to monitor shifts in social and ecological systems

A replacement program for infrastructure/gear and insurance protection lessen the likelihood that managers and operators will be taken by surprise when social and/or ecological conditions change 
7. Openness to resilience ideas

8. Potential to reorganize
Insurance protection

Operator/manager/scientist forums including climate change science

Engagement with socialecological learning

Forms of social decision making to enhance long-term sustainability and resilience

Understanding of social Strategies to build social capital capital and networks

Openness to transformational Processes of critical reflection change

in place to reevaluate norms, values, and rules

I Climate change policies Policies in place

Planning for extreme events Strategies and plans in place

Use of future or anticipatory Scenario and other futures planning techniques Adoption of adaptive management approaches

P Infrastructure flexibility

Ec Natural variability in physiological tolerances

Functional diversity and redundancy

Quantification of species' performance at physiological limits

Indicators of species richness/ diversity

Degree of niche overlap Trophic changes

Healthy ecosystems, habitats, Ecosystem integrity index and biodiversity

S Openness to innovation

Evidence of innovative environmental management: policies, production, greenhouse gas pollution, recycling, etc.

Consumers' ability to revise Shifts to alternative seafood preferences and/or tourism preferences

Stocks of social capital and trust

Level of educational

attainment

Employment training and experience

Preparedness for change

E Economic buffering
Levels of trust in industry/ sector decision makers Employees with a postsecondary/tertiary qualification Experience/training in other industries

Perceptions of ability to cope with and adapt to change

Diversification trends
Engagement with science helps to build a sense of trust in and ownership of the science

Learning is essential in dealing with change and surprise

Social capital and networks help to lower the transaction costs of undertaking collective action

When a system state becomes untenable, the system needs to be reconceptualized

Climate change policies are evidence of political will to act on climate change

Instability caused by climate change impacts is likely to increase as the climate becomes more unstable

Anticipatory planning will lower the potential for surprise

Adaptive management accepts the uncertainty of resource management conditions viewing policy as a process of hypothesis testing and learning through implementation to improve the state of knowledge.

Flexibility provides the capacity to respond to unexpected changes in desired species movements or damage to tourism infrastructure as a result of extreme weather events Changing environmental conditions will likely change how species perform in new environments; understanding if/how species will perform/survive under new conditions will lend greater certainty to ecological forecasts.

Healthy ecosystems will have high levels of biodiversity and functional redundancy; these ecosystems will be best placed to respond to perturbations and changing environmental conditions.

Considering multiple indices of ecosystem health simultaneously may provide a more holistic picture of ecosystem integrity than single indicators considered in isolation.

Actors need to be able to take advantage of windows of opportunity that open up during the reorganization phase of an adaptive cycle.

Operators' capacity to reorganize their businesses in response to climate change impacts is in part dependent on consumers' ability to revise their preferences toward alternative marine products

Social capital and trust are crucial for the collaborative engagement needed to reorganize sectors

Higher levels of educational attainment generally facilitate capacities for change

Experience in other industries can influence openness to change

Individuals' level of resource dependency affects their ability to be resilient through their assessment of risk, perceived ability to experiment, and to plan and reorganize

Diversification reduces the possibility of negative impacts of change and increases the options for successful responses to change 


\begin{tabular}{|c|c|c|c|}
\hline \multirow[b]{2}{*}{ I } & \multirow[b]{2}{*}{ Multilevel networks } & \multicolumn{2}{|l|}{ Profitability } \\
\hline & & Integrated governance & $\begin{array}{l}\text { Integrated multilevel governance increases the capacity for } \\
\text { coordination across governance levels and reduces the likelihood } \\
\text { of a mismatch between governance system and ecosystem }\end{array}$ \\
\hline & $\begin{array}{l}\text { Flexibility of rules and } \\
\text { governance }\end{array}$ & $\begin{array}{l}\text { Ongoing dialogue among } \\
\text { industry stakeholders }\end{array}$ & $\begin{array}{l}\text { Some flexibility of institutions and instruments is needed to } \\
\text { support adaptive governance }\end{array}$ \\
\hline & Stakeholder inclusiveness & $\begin{array}{l}\text { Operators' involvement in } \\
\text { management plans }\end{array}$ & $\begin{array}{l}\text { Inclusiveness provides support for the idea that diverse sources } \\
\text { of knowledge are needed in solving complex problems and to } \\
\text { ensure stakeholders' ongoing commitment to building resilience }\end{array}$ \\
\hline & $\begin{array}{l}\text { Commitments to monitoring } \\
\text { and evaluation }\end{array}$ & $\begin{array}{l}\text { Monitoring and evaluation } \\
\text { programs }\end{array}$ & $\begin{array}{l}\text { Monitoring aids the social and adaptive learning that is needed in } \\
\text { responding to change }\end{array}$ \\
\hline & Infrastructure flexibility & $\begin{array}{l}\text { Capacity to relocate or change } \\
\text { target species }\end{array}$ & $\begin{array}{l}\text { Infrastructure and gear flexibility allow operators to respond as } \\
\text { required to locational and qualitative shifts in target species and } \\
\text { policy changes }\end{array}$ \\
\hline & & Operators with flexibility & $\begin{array}{l}\text { Operators also need to be flexible to take advantage of the } \\
\text { flexibility of gear, area, etc., and make rapid changes when the } \\
\text { need arises }\end{array}$ \\
\hline
\end{tabular}

\footnotetext{
${ }^{\dagger}$ Ec refers to ecological assets; $S$ includes social and human assets; E refers to economic and financial assets; I includes institutional, policy, and political dimensions; and P refers to physical, including infrastructural, technical, and technological assets.
}

- raising awareness of the breadth of internal and external preconditions for marine sector resilience, i.e., economic, financial, ecological, social, institutional, political, and physical;

- raising public awareness of resilience problems and their interconnectedness;

- making complex concepts meaningful and comprehensible by helping to develop a common language for discussion;

- helping stakeholders to understand resilience and to read resilience trends;

- informing decision making so that it is founded on logical, coherent, and transparent information;

- setting targets to improve resilience of a sector or sphere of activity that scores low on specific resilience dimensions or variables; and

- highlighting trends that can strengthen general and specific resilience of stakeholders and that of their sectors.

With refinement, this framework can ultimately be expected to support the operationalization of resilience concepts by: (1) guiding policy analysis and formulation toward more resilient marine sectors either directly, conceptually, or symbolically (Gudmundsson 2003); (2) developing operational approaches to benchmark, monitor, evaluate, and report on marine sector resilience; and (3) assisting marine sector decision makers and managers to embrace complexity and operate more effectively and easily in a context of uncertainty. The overall purpose of the framework is to guide marine sectors toward a more resilient orientation (Darnhofer et al. 2010, Cabell and Oelofse 2012).
To advance the framework, the next steps include its further testing and refinement within applied resilience-based management contexts. This could be achieved through participatory action research on resilience metrics and techniques to facilitate selection of key indicators, i.e., those that relate to multiple resilience dimensions and are representative of overall resilience performance, and so reduce the number of indicators. As a starting point, in Table 5, we offer a list of candidate variables, those found to recur in the framework. These are categorized in terms of generic resilience perspectives that could help facilitate dialogue to identify a subset of predictive or leading indicators, which are used to signal potentially significant change toward or away from desirable resilience states. For example, it may be important for resilience planning to identify which social or ecological components are more or less vulnerable, resistant, or resilient to change. Leading indicators are therefore essential to long-range or strategic planning, monitoring progress on resilience, and anticipatory adaptation.

Further indicator development would ideally involve collaboration with stakeholders in the diagnosis process to ensure relevance and social-ecological learning. Although much of the data for the framework originated in work undertaken by researchers with stakeholder groups, the data were inevitably filtered through expert perspectives.

Ultimately, the expectation for a more mature framework would be one that is able to map resilience, measure progress, and assist in setting priorities, while lessons from its application would further inform the conceptual and especially practical development and implementation of resilience. 
Table 5. Potential key indicators.

\begin{tabular}{l}
\hline Resilience perspective \\
Ecological resilience \\
(capacity of ecosystems to absorb disturbance and \\
maintain healthy habitats and biodiversity; \\
important for supporting diverse ecological and \\
social communities)
\end{tabular}

Candidate variables for key indicators of marine sector resilience

Status of key habitats

(2)

Availability of refuge habitat

Climate change impacts (extreme events, sea temperatures, catchment runoff, acidification, sea level rise)

Status of keystone species

Invasive species trends

Functional diversity and redundancy

Social resilience

(ability of individuals and groups to cope with

Consumer preferences

and adapt to environmental and

social change and withstand shocks to their social infrastructure ${ }^{\dagger}$ )

Economic resilience
(policy-induced ability of a sector's economy to
recover from, adapt to, or avoid/withstand the effects of adverse economic and other shocks ${ }^{\star}$ )

Institutional resilience

(ability of institutions to withstand disturbances by providing both stability to reduce uncertainty and flexibility to respond to the uncertainties of changing external conditions ${ }^{\S}$ )

Infrastructural resilience

(operators' physical capacity to respond to and recover from disturbance or change in operating conditions)

Infrastructure longevity
Insurance protection

Replacement planning

Employment trends

Industry impacts

Power relations

Governance legitimacy
Public perceptions (e.g., of environmental decline, risk)

Social capital, networks, and trust

Social-ecological learning

Openness to and preparedness for change and innovation among resource users, decision makers, managers, and community

Education, experience, and training

Buffering capacity (profitability, asset value, diversification)

External conditions (domestic and export markets, exchange rates)

Stock or tourism destination changes

Changes in resource harvest or visitor numbers

Supportive policy environment (political will and leadership)

Institutional design (integrated governance and management, adaptive governance and management, monitoring, critical reflection processes, inclusiveness, flexibility)

Viability of risk response (extreme events, strategies and plans, scenario planning)

Flexibility (gear, infrastructure, location)

${ }^{\dagger}$ Adger 2000

Briguglio et al. 2009

${ }^{\S}$ Steinberg 2009, Herrfahrdt-Pähle and Pahl-Wostl 2012 
Responses to this article can be read online at: http://www.ecologyandsociety.org/issues/responses. $\mathrm{php} / 5607$

\section{Acknowledgments:}

The authors wish to express their sincere gratitude for the constructive feedback of two reviewers, whose comments and input have contributed in a substantial way to the refinement and ultimate quality of the paper. We also thank the journal editors for their helpful direction and productive input. We gratefully acknowledge support from Australia's Climate Change Adaptation Research Network for Marine Biodiversity and Resources.

\section{LITERATURE CITED}

Adger, W. N. 2000. Social and ecological resilience: are they related? Progress in Human Geography 24(3):347-364. http:// dx.doi.org/10.1191/030913200701540465

Badjeck, M.-C., E. H. Allison, A. S. Halls, and N. K. Dulvy. 2010. Impacts of climate variability and change on fisherybased livelihoods. Marine Policy 34(3):375-383. http://dx.doi. org/10.1016/j.marpol.2009.08.007

Béné, C., L. Evans, D. Mills, S. Ovie, A. Raji, A. Tafida, A. Kodio, F. Sinaba, P. Morand, J. Lemoalle, and N. Andrew. 2011. Testing resilience thinking in a poverty context: experience from the Niger River basin. Global Environmental Change 21(4):1173-1184. http://dx.doi.org/10.1016/j. gloenvcha.2011.07.002

Bennett, E. M., G. S. Cumming, and G. D. Peterson. 2005. A systems model approach to determining resilience surrogates for case studies. Ecosystems 8(8):945-957. http://dx.doi. org/10.1007/s10021-005-0141-3

Berkes, F. 2007. Understanding uncertainty and reducing vulnerability: lessons from resilience thinking. Natural Hazards 41(2):283-295. http://dx.doi.org/10.1007/s11069-006-9036-7

Bohensky, E. L. 2008. Discovering resilient pathways for South African water management: two frameworks for a vision. Ecology and Society 13(1): 19. [online] URL: http:// www.ecologyandsociety.org/vol13/iss 1/art19

Booher, D. E., and J. E. Innes. 2010. Governance for resilience: CALFED as a complex adaptive network for resource management. Ecology and Society 15(3): 35. [online] URL: http://www.ecologyandsociety.org/vol15/iss3/art35/

Bourdieu, P. 1999. Structures, habitus, practices. Pages 441-446 in C. C. Lemert, editor. Social theory: the multicultural and classic readings. Westview, Boulder, Colorado, USA.
Brand, F. S., and K. Jax. 2007. Focusing the meaning(s) of resilience: resilience as a descriptive concept and a boundary object. Ecology and Society 12(1): 23. [online] URL: http:// www.ecologyandsociety.org/vol12/iss1/art23/

Brander, K. 2010. Impacts of climate change on fisheries. Journal of Marine Systems 79(3-4):389-402. http://dx.doi. org/10.1016/j.jmarsys.2008.12.015

Briguglio, L., G. Cordina, N. Farrugia, and S. Vella. 2009. Economic vulnerability and resilience: concepts and measurements. Oxford Development Studies 37(3):229-247. http://dx.doi.org/10.1080/13600810903089893

Cabell, J. F., and M. Oelofse. 2012. An indicator framework for assessing agroecosystem resilience. Ecology and Society 17(1): 18. http://dx.doi.org/10.5751/ES-04666-170118

Carpenter, S. R., F. Westley, and M. G. Turner. 2005. Surrogates for resilience of social-ecological systems. Ecosystems 8(8):941-944. http://dx.doi.org/10.1007/s10021-005-0170$\mathrm{y}$

Chapin, III, F. S., G. Kofinas, and C. Folke. 2009. A framework for understanding change. Pages 3-28 in F. S. Chapin, III, G. Kofinas, and C. Folke, editors. Principles of ecosystem stewardship: resilience-based natural resource management in a changing world. Springer, New York, New York, USA. http://dx.doi.org/10.1007/978-0-387-73033-2 1

Cinner, J., M. M. P. B. Fuentes, and H. Randriamahazo. 2009. Exploring social resilience in Madagascar's marine protected areas. Ecology and Society 14(1): 41. [online] URL: http:// www.ecologyandsociety.org/vol14/iss1/art41/

Coghlan, A., and B. Prideaux. 2009. Welcome to the wet tropics: the importance of weather in reef tourism resilience. Current Issues in Tourism 12:89-104. http://dx.doi. org/10.1080/13683500802596367

Crowder, L. B., E. L. Hazen, N. Avissar, R. Bjorkland, C. Latanich, and M. B. Ogburn. 2008. The impacts of fisheries on marine ecosystems and the transition to ecosystem-based management. Annual Review of Ecology, Evolution, and Systematics 39:259-278. http://dx.doi.org/10.1146/annurev. ecolsys.39.110707.173406

Cumming, G. S., G. Barnes, S. Perz, M. Schmink, K. E. Sieving, J. Southworth, M. Binford, R. D. Holt, C. Stickler, and T. Van Holt. 2005. An exploratory framework for the empirical measurement of resilience. Ecosystems 8 (8):975-987. http://dx.doi.org/10.1007/s10021-005-0129-z

Cutter, S. L., L. Barnes, M. Berry, C. Burton, E. Evans, E. Tate, and J. Webb. 2008. A place-based model for understanding community resilience to natural disasters. Global Environmental Change 18(4):598-606. http://dx.doi. org/10.1016/j.gloenvcha.2008.07.013 
Darnhofer, I., J. Fairweather, and H. Moller. 2010. Assessing a farm's sustainability: insights from resilience thinking. International Journal of Agricultural Sustainability 8:186-198. http://dx.doi.org/10.3763/ijas.2010.0480

De'ath, G., and K. E. Fabricius. 2008. Water quality of the Great Barrier Reef: distributions, effects on reef biota and trigger values for the protection of ecosystem health. Final Report to the Great Barrier Reef Marine Park Authority, Australian Institute of Marine Science, Townsville, Australia. [online] URL: http://elibrary.gbrmpa.gov.au/jspui/

bitstream/11017/416/1/Water-quality-of-the-Great-Barrier-Reefdistributions-effects-on-reef-biota-and-trigger-values-for-theprotection-of-ecosystem-health.pdf

De'ath, G., J. M. Lough, and K. E. Fabricius. 2009. Declining coral calcification on the Great Barrier Reef. Science 323 (5910):116-119. http://dx.doi.org/10.1126/science.1165283

deYoung, B., M. Barange, G. Beaugrand, R. Harris, R. I. Perry, M. Scheffer, and F. Werner. 2008. Regime shifts in marine ecosystems: detection, prediction and management. Trends in Ecology and Evolution 23(7):402-409. http://dx.doi. org/10.1016/j.tree.2008.03.008

deYoung, B., R. Harris, J. Alheit, G. Beaugrand, N. Mantua, and L. Shannon. 2004. Detecting regime shifts in the ocean: data considerations. Progress in Oceanography 60 (2-4):143-164. http://dx.doi.org/10.1016/j.pocean.2004.02.017

Dove, M. C., and J. Sammut. 2007. Impacts of estuarine acidification on survival and growth of Sydney rock oysters Saccostrea glomerata (Gould 1850). Journal of Shellfish Research 26:519-527. http://dx.doi.org/10.2983/0730-8000 (2007)26[519:IOEAOS]2.0.CO;2

Eakin, H., and A. L. Luers. 2006. Assessing the vulnerability of social-environmental systems. Annual Review of Environment and Resources 31:365-394. http://dx.doi. org/10.1146/annurev.energy.30.050504.144352

Eberhard Consulting. 2011. Caring for Our Country - Reef Rescue as a program delivery model for natural resource management. Australian Department of Sustainability, Environment, Water, Population and Communities, Canberra, Australia.

Fabricius, K. E. 2011. Factors determining the resilience of coral reefs to eutrophication: a review and conceptual model. Pages 493-505 in Z. Dubinsky and N. Stambler, editors. Coral reefs: an ecosystem in transition. Springer, New York, New York, USA. http://dx.doi.org/10.1007/978-94-007-0114-4 28

Fenton, M., G. Kelly, K. Vella, and J. Innes. 2007. Climate change and Great Barrier Reef: industries and communities. Pages 746-771 in J. E. Johnson and P. A. Marshall, editors. Climate change and the Great Barrier Reef. Great Barrier Reef Marine Park Authority and Australian Greenhouse Office,
Townsville, Australia. [online] URL: http://www.gbrmpa. gov.au/ data/assets/pdf file/0020/5438/chpt-23-fenton-et-al-2007. pdf

Fisheries Research and Development Corporation. 2010. Climate change, marine biodiversity and the fishing and aquaculture industries. Fisheries Research and Development Corporation, Deakin, Australia. [online] URL: http://frdc. com.au/knowledge/Factsheets/Factsheet\%20-\%20Fisheries\% 20Climate\%20Change.pdf

Flyvbjerg, B. 2006. Five misunderstandings about case-study research. Qualitative Inquiry 12(2):219-245. http://dx.doi. org/10.1177/1077800405284363

Folke, C. 2006. Resilience: the emergence of a perspective for social-ecological systems analyses. Global Environmental Change 16:253-267. http://dx.doi.org/10.1016/j.

gloenvcha.2006.04.002

Folke, C., J. Colding, and F. Berkes. 2003. Synthesis: building resilience and adaptive capacity in social-ecological systems. Pages 352-387 in F. Berkes, J. Colding, and C. Folke, editors. Navigating social-ecological systems: building resilience for complexity and change. Cambridge University Press, Cambridge, UK. http://dx.doi.org/10.1017/CBO9780511541957.020

Great Barrier Reef Marine Park Authority. 2009. Great Barrier Reef Outlook Report 2009. Great Barrier Reef Marine Park Authority, Townsville, Queensland, Australia. [online] URL: http://www.gbrmpa.gov.au/ data/assets/pdf file/0018/3843/ OutlookReport Full.pdf

Green, B. S., C. Gardner, A. Linnane, and P. J. Hawthorne. 2010. The good, the bad and the recovery in an assisted migration. PLoS ONE 5:e14160. http://dx.doi.org/10.1371/ journal.pone.0014160

Grosskurth, J., and J. Rotmans. 2007. Qualitative system sustainability index: a new type of sustainability indicator. Pages 177-188 in T. Hák, B. Moldan, and A. L. Dahl, editors. Sustainability indicators: a scientific assessment. Island, Washington, D.C., USA.

Gudmundsson, H. 2003. The policy use of environmental indicators - learning from evaluation research. Journal of Transdisciplinary Environmental Studies 2:1-12. [online] URL: http://www.journal-tes.dk/vol\%202\%20no\%202/ Henrik Gudnundsson lav.pdf

Gunderson, L. H. 2003. Adaptive dancing: interactions between social resilience and ecological crises. Pages 33-52 in F. Berkes, J. Colding, and C. Folke, editors. Navigating social-ecological systems: building resilience for complexity and change. Cambridge University Press, Cambridge, UK. http://dx.doi.org/10.1017/CBO9780511541957.005 
Gunderson, L. H., and C. S. Holling, editors. 2002. Panarchy: understanding transformations in human and natural systems. Island, Washington, D.C., USA.

Hallegraeff, G. M. 2010. Ocean climate change, phytoplankton community responses, and harmful algal blooms: a formidable predictive challenge. Journal of Phycology 46(2):220-235. http://dx.doi.org/10.1111/ j.1529-8817.2010.00815.x

Hamon, K. G., S. D. Frusher, L. R. Little, O. Thébaud, and A. E. Punt. 2013. Adaptive behaviour of fishers to external perturbations: simulation of the Tasmanian rock lobster fishery. Reviews in Fish Biology and Fisheries January 2013. http://dx.doi.org/10.1007/s11160-013-9302-1

Harley, C. D. G., A. Randall Hughes, K. M. Hultgren, B. G. Miner, C. J. B. Sorte, C. S. Thornber, L. F. Rodriguez, L. Tomanek, and S. L. Williams. 2006. The impacts of climate change in coastal marine systems. Ecology Letters 9 (2):228-241. http://dx.doi.org/10.1111/j.1461-0248.2005.00871. $\underline{\mathrm{X}}$

Haward, M., J. Davidson, M. Lockwood, M. Hockings, L. Kriwoken, and R. Allchin. 2013. Climate change, scenarios and marine biodiversity conservation. Marine Policy 38:438-446. http://dx.doi.org/10.1016/j.marpol.2012.07.004

Herrfahrdt-Pähle, E., and C. Pahl-Wostl. 2012. Continuity and change in social-ecological systems: the role of institutional resilience. Ecology and Society 17(2): 8. http://dx.doi. org/10.5751/ES-04565-170208

Hoegh-Guldberg, O., P. J. Mumby, A. J. Hooten, R. S. Steneck, P. Greenfield, E. Gomez, C. D. Harvell, P. F. Sale, A. J. Edwards, K. Caldeira, N. Knowlton, C. M. Eakin, R. Iglesias-Prieto, N. Muthiga, R. H. Bradbury, A. Dubi, and M. E. Hatziolos. 2007. Coral reefs under rapid climate change and ocean acidification. Science 318:1737-1742. http://dx.doi. org/10.1126/science.1152509

Holbrook, N. J., and N. L. Bindoff. 1997. Interannual and decadal temperature variability in the southwest Pacific Ocean between 1955 and 1988. Journal of Climate 10(5):1035-1049. http://dx.doi.org/10.1175/1520-0442(1997)010<1035:IADTVI>2.0. $\underline{\mathrm{CO} ; 2}$

Holling, C. S. 2001. Understanding the complexity of economic, ecological, and social systems. Ecosystems 4 (5):390-405. http://dx.doi.org/10.1007/s10021-001-0101-5

Howard, W., D. Roberts, A. Moy, J. Roberts, T. Trull, S. Bray, and R. Hopcroft. 2009. Ocean acidification impacts on southern ocean calcifiers. IOP conference series: earth and environmental science 6. Climate change: global risks, challenges and decisions: session: 46 - consequences of acidification of land and ocean. IOP, Bristol, UK.
Hughes, T. P., D. R. Bellwood, C. S. Folke, L. J. McCook, and J. M. Pandolfi. 2007. No-take areas, herbivory and coral reef resilience. Trends in Ecology and Evolution 22(1):1-3. http://dx.doi.org/10.1016/j.tree.2006.10.009

Hughes, T. P., N. A. J. Graham, J. B. C. Jackson, P. J. Mumby, and R. S. Steneck. 2010. Rising to the challenge of sustaining coral reef resilience. Trends in Ecology and Evolution 25 (11):633-642. http://dx.doi.org/10.1016/j.tree.2010.07.011

Hughes, T. P., M. J. Rodrigues, D. R. Bellwood, D. Ceccarelli, O. Hoegh-Guldberg, L. McCook, N. Moltschaniwskyj, M. S. Pratchett, R. S. Steneck, and B. Willis. 2007. Phase shifts, herbivory, and the resilience of coral reefs to climate change. Current Biology 17(4):360-365. http://dx.doi.org/10.1016/j. cub.2006.12.049

Huybers, T., and J. Bennett. 2000. Impact of the environment on holiday destination choices of prospective UK tourists: implications for Tropical North Queensland. Tourism Economics 6:21-46. http://dx.doi.org/10.5367/000000000101297451

Johnson, C. R., S. C. Banks, N. S. Barrett, F. Cazassus, P. K. Dunstan, G. J. Edgar, S. D. Frusher, C. Gardner, M. Haddon, F. Helidoniotis, K. L. Hill, N. J. Holbrook, G. W. Hosie, P. R. Last, S. D. Ling, J. Melbourne-Thomas, K. Miller, G. T. Pecl, A. J. Richardson, K. R. Ridgway, S. R. Rintoul, D. A. Ritz, D. J. Ross, J. C. Sanderson, S. A. Shepherd, A. Slotwinski, K. M. Swadling, and N. Taw. 2011. Climate change cascades: shifts in oceanography, species' ranges and subtidal marine community dynamics in eastern Tasmania. Journal of Experimental Marine Biology and Ecology 400(1-2):17-32. http://dx.doi.org/10.1016/j.jembe.2011.02.032

Kofinas, G. P., and F. S. Chapin, III. 2009. Sustaining livelihoods and human well-being during social-ecological change. Pages 55-75 in F. S. Chapin, III, G. P. Kofinas, and C. Folke, editors. Principles of ecosystem stewardship: resilience-based natural resource management in a changing world. Springer, New York, New York, USA.

Last, P. R., W. T. White, D. C. Gledhill, A. J. Hobday, R. Brown, G. J. Edgar, and G. Pecl. 2010. Long-term shifts in abundance and distribution of a temperate fish fauna: a response to climate change and fishing practices. Global Ecology and Biogeography 20(1):58-72. http://dx.doi. org/10.1111/j.1466-8238.2010.00575.X

Leith, P. B., and M. Haward. 2010. Climate change adaptation in the Australian edible oyster industry: an analysis of policy and practice. University of Tasmania, Hobart, Tasmania, Australia. [online] URL: http://arnmbr.org/content/images/ uploads/OYSTER_REPORT_FINAL_web.pdf

Levin, S. A., and J. Lubchenco. 2008. Resilience, robustness, and marine ecosystem-based management. BioScience 58 (1):27-32. http://dx.doi.org/10.1641/B580107 
Ling, S. D., C. R. Johnson, S. D. Frusher, and K. R. Ridgway. 2009. Overfishing reduces resilience of kelp beds to climatedriven catastrophic phase shift. Proceedings of the National Academy of Sciences 106(52):22341-22345. http://dx.doi. org/10.1073/pnas.0907529106

Linnane, A., C. Gardner, D. Hobday, A. Punt, R. McGarvey, J. Feenstra, J. Matthews, and B. Green. 2010. Evidence of large-scale spatial declines in recruitment patterns of southern rock lobster Jasus edwardsii, across south-eastern Australia. Fisheries Research 105:163-171. http://dx.doi.org/10.1016/j. fishres.2010.04.001

Liu, J., T. Dietz, S. R. Carpenter, M. Alberti, C. Folke, E. Moran, A. N. Pell, P. Deadman, T. Kratz, J. Lubchenco, E. Ostrom, Z. Ouyang, W. Provencher, C. L. Redman, S. H. Schneider, and W. W. Taylor. 2007. Complexity of coupled human and natural systems. Science 317(5844):1513-1516. http://dx.doi.org/10.1126/science.1144004

Madin, E. M. P., N. C. Ban, Z. A. Doubleday, T. H. Holmes, G. T. Pecl, and F. Smith. 2012. Socio-economic and management implications of range-shifting species in marine systems. Global Environmental Change 22(1):137-146. http:// dx.doi.org/10.1016/j.gloenvcha.2011.10.008

Malcolm, H. A., P. L. Davies, A. Jordan, and S. D. A. Smith. 2011. Variation in sea temperature and the East Australian Current in the Solitary Islands region between 2001-2008. Deep Sea Research Part II: Topical Studies in Oceanography 58:616-627. http://dx.doi.org/10.1016/j.dsr2.2010.09.030

Malone, E. L., and A. L. Brenkert. 2008. Uncertainty in resilience to climate change in India and Indian states. Climatic Change 91(3-4):451-476. http://dx.doi.org/10.1007/ s10584-008-9472-3

Marshall, N. A. 2010. Understanding social resilience to climate variability in primary enterprises and industries. Global Environmental Change 20(1):36-43. http://dx.doi. org/10.1016/j.gloenvcha.2009.10.003

Marshall, N. A., D. M. Fenton, P. A. Marshall, and S. G. Sutton. 2007. How resource dependency can influence social resilience within a primary resource industry. Rural Sociology 72:359-390.

Marshall, N. A., and P. A. Marshall. 2007. Conceptualizing and operationalizing social resilience within commercial fisheries in northern Australia. Ecology and Society 12(1): 1. [online] URL: http://www.ecologyandsociety.org/vol12/iss 1/ $\underline{\operatorname{art} 1 /}$

Marshall, N. A., P. A. Marshall, J. Tamelander, D. Obura, D. Malleret-King, and J. E. Cinner. 2009. A framework for social adaptation to climate change:sustaining tropical coastal communities and industries. International Union for Conservation of Nature, Gland, Switzerland.
Mumby, P. J., C. P. Dahlgren, A. R. Harborne, C. V. Kappel, F. Micheli, D. R. Brumbaugh, K. E. Holmes, J. M. Mendes, K. Broad, J. N. Sanchirico, K. Buch, S. Box, R. W. Stoffle, and A. B. Gill. 2006. Fishing, trophic cascades, and the process of grazing on coral reefs. Science 311(5757):98-101. http:// dx.doi.org/10.1126/science.1121129

Nell, J. 2007. Diseases of Sydney rock oysters. NSW DPI Primefacts: Profitable and Sustainable Primary Industries 589:1-4. [online] URL: http://www.extension.org/sites/ default/files/Diseases\%20of\%20Sydney\%20Rock\%200ysters. pdf

Nelson, D. R., W. N. Adger, and K. Brown. 2007. Adaptation to environmental change: contributions of a resilience framework. Annual Review of Environment and Resources 32:395-419. http://dx.doi.org/10.1146/annurev.

energy.32.051807.090348

Newell, W. H. 2001. A theory of interdisciplinary studies. Issues in Integrative Studies 19:1-25.

Niemeijer, D., and R. S. de Groot. 2008. Framing environmental indicators: moving from causal chains to causal networks. Environment, Development and Sustainability 10 (1):89-106. http://dx.doi.org/10.1007/s10668-006-9040-9

Nyström, M., N. A. J. Graham, J. Lokrantz, and A. V. Norstrom. 2008. Capturing the cornerstones of coral reef resilience: linking theory to practice. Coral Reefs 27 (4):795-809. http://dx.doi.org/10.1007/s00338-008-0426-z

Olsson, P., C. Folke, and T. Hahn. 2004. Social-ecological transformation for ecosystem management: the development of adaptive co-management of a wetland landscape in southern Sweden. Ecology and Society 9(4): 2. [online] URL: http:// www.ecologyandsociety.org/vol9/iss4/art2/

Olsson, P., L. H. Gunderson, S. R. Carpenter, P. Ryan, L. Lebel, C. Folke, and C. S. Holling. 2006. Shooting the rapids: navigating transitions to adaptive governance of socialecological systems. Ecology and Society 11(1): 18. [online] URL: http://www.ecologyandsociety.org/vol11/iss1/art18/

Ostrom, E. 2011. Background on the institutional analysis and development framework. Policy Studies Journal 39(1):7-27. http://dx.doi.org/10.1111/j.1541-0072.2010.00394.x

Oxford Economics. 2009. Valuing the effects of Great Barrier Reef bleaching. Great Barrier Reef Foundation, Brisbane, Australia. [online] URL: http://www.barrierreef.org/Portals/0/ Oxford report/GBRF OxfordReport Final WEB.pdf

Pearce, A., and M. Feng. 2007. Observations of warming on the Western Australian continental shelf. Marine and Freshwater Research 58(10):914-920. http://dx.doi.org/10.1071/ MF07082 
Pecl, G. 2011. Cephalopods moving southwards to avoid the heat. Malacological Society of Australasia Newsletter 141:1-2. [online] URL: http://www.malsocaus.org/newsletter/ ASN141.pdf

Pecl, G., S. Frusher, C. Gardner, M. Haward, A. Hobday, S. Jennings, M. Nursey-Bray, A. Punt, H. Revill, and I. van Putten. 2009. The east coast Tasmanian rock lobster fishery vulnerability to climate change impacts and adaptation response options. Department of Climate Change, Australian Government, Canberra, Australia. [online] URL: http://www. cakex.org/sites/default/files/rock-lobser-report-low-res-pdf.pdf

Poloczanska, E. S., R. C. Babcock, A. Buttler, A. J. Hobday, O. Hoegh-Guldberg, T. J. Kunz, R. Matear, D. A. Milton, T. A. Okey, and A. J. Richardson. 2007. Climate Change and Australian marine life. Oceanography and Marine Biology: an Annual Review 45:407-478.

Poloczanska, E. S., A. J. Hobday, and A. J. Richardson, editors. 2012. Marine climate change in Australia: impacts and adaptation responses. 2012 report card. CSIRO, Brisbane, Australia. [online] URL: http://www.oceanclimatechange. org.au/content/images/uploads/Marine Report Card Australia 2012. pdf

Pretty, J. N. 1995. Participatory learning for sustainable agriculture. World Development 23:1247-1263. http://dx.doi. org/10.1016/0305-750X(95)00046-F

Reed, M. S., E. D. G. Fraser, and A. J. Dougill. 2006. An adaptive learning process for developing and applying sustainability indicators with local communities. Ecological Economics 59:406-418. http://dx.doi.org/10.1016/j. ecolecon.2005.11.008

Resilience Alliance. 2007. Assessing resilience in socialecological systems: a workbook for scientists. Resilience Alliance. [online] URL: http://www.seachangecop.org/sites/ default/files/documents/2007\%2006\%20RA\%20assesing\% 20Resilience\%20in\%20SES\%20-\%20Scientists\%20Workbook. pdf

Richardson, A. J., and E. S. Poloczanska. 2008. Ocean science: under-resourced, under threat. Science 320(5881):1294-1295. http://dx.doi.org/10.1126/science.1156129

Ridgway, K. R. 2007. Long-term trend and decadal variability of the southward penetration of the East Australian Current. Geophysical Research Letters 34(13):L13613. http://dx.doi. org/10.1029/2007GL030393

Robinson, L. W., and F. Berkes. 2010. Applying resilience thinking to questions of policy for pastoralist systems: lessons from the Gabra of northern Kenya. Human Ecology 38 (3):335-350. http://dx.doi.org/10.1007/s10745-010-9327-1

Scheffer, M. 2009. Critical transitions in nature and society. Princeton University Press, Princeton, New Jersey, USA.
Scoones, I. 1998. Sustainable rural livelihoods: a framework for analysis. IDS Working Paper 72, Institute of Development Studies, Brighton, UK. [online] URL: http://www.ids.ac.uk/ files/dmfile/Wp72.pdf

Scoones, I. 2009. Livelihoods perspectives and rural development. Journal of Peasant Studies 36(1):171-196. http://dx.doi.org/10.1080/03066150902820503

Stake, R. E. 2000. Case studies. Pages 435-454 in N. K. Denzin and Y. S. Lincoln, editors. Handbook of qualitative research. Sage, Thousand Oaks, California, USA.

Steinberg, P. F. 2009. Institutional resilience amid political change: the case of biodiversity conservation. Global Environmental Politics 9(3):61-81. http://dx.doi.org/10.1162/ glep.2009.9.3.61

Thompson, P. A., M. E. Baird, T. Ingleton, and M. A. Doblin. 2009. Long-term changes in temperate Australian coastal waters: implications for phytoplankton. Marine Ecology Progress Series 394:1-19. http://dx.doi.org/10.3354/meps08297

Thompson, A. A., and A. M. Dolman. 2010. Coral bleaching: one disturbance too many for near-shore reefs of the Great Barrier Reef. Coral Reefs 29:637-648. http://dx.doi. org/10.1007/s00338-009-0562-0

Thrush, S. F., J. E. Hewitt, P. K. Dayton, G. Coco, A. M. Lohrer, A. Norkko, J. Norkko, and M. Chiantore. 2009. Forecasting the limits of resilience: integrating empirical research with theory. Proceedings of the Royal Society B: Biological Sciences 276(1671):3209-3217. http://dx.doi. org/10.1098/rspb.2009.0661

Tittensor, D. P., C. Mora, W. Jetz, H. K. Lotze, D. Ricard, E. Vanden Berghe, and B. Worm. 2010. Global patterns and predictors of marine biodiversity across taxa. Nature 466:1098-1101. http://dx.doi.org/10.1038/nature09329

van der Heijden, K. 1996. Scenarios: the art of strategic conversation. John Wiley and Sons, Chichester, UK.

van Putten, I., and C. Gardner. 2010. Lease quota fishing in a changing rock lobster industry. Marine Policy 34(5): 859-867. http://dx.doi.org/10.1016/j.marpol.2010.01.008

Walker, B., S. Carpenter, J. Anderies, N. Abel, G. S. Cumming, M. Janssen, L. Lebel, J. Norberg, G. D. Peterson, and R. Pritchard. 2002. Resilience management in socialecological systems: a working hypothesis for a participatory approach. Conservation Ecology 6(1): 14. [online] URL: http://www.consecol.org/vol6/iss1/art14/

Walker, B., and J. A. Meyers. 2004. Thresholds in ecological and social-ecological systems: a developing database. Ecology and Society 9(2): 3 [online] URL: http://www. ecologyandsociety.org/vol9/iss2/art3/ 
Walker, B., and D. Salt. 2006. Resilience thinking: sustaining ecosystems and people in a changing world. Island, Washington, D.C., USA.

Walmsley, J. J. 2002. Framework for measuring sustainable development in catchment systems. Environmental Management 29(2):195-206. http://dx.doi.org/10.1007/

s00267-001-0020-4

Westley, F. 2002. The devil in the dynamics: adaptive management on the front lines. Pages 333-360 in L. H. Gunderson and C. S. Holling, editors. Panarchy: understanding transformations in human and natural systems. Island, Washington, D.C., USA.

Wielgus, J., N. E. Chadwick-Furman, and Z. Dubinsky. 2004. Coral cover and partial mortality on anthropogenically impacted coral reefs at Eilat, northern Red Sea. Marine Pollution Bulletin 48:248-253. http://dx.doi.org/10.1016/j. marpolbul.2003.08.008

Wilson, R. F., and S. M. Turton. 2010. The impact of climate change on reef-based tourism in Cairns, Australia - adaptation and response strategies for a highly vulnerable destination. Pages 233-253 in A. Jones and M. Phillips, editors. Disappearing destinations: climate change and the future challenges for coastal tourism. CABI, Wallingford, UK.

Young, O. R. 2010. Institutional dynamics: resilience, vulnerability and adaptation in environmental and resource regimes. Global Environmental Change 20(3):378-385. http:// dx.doi.org/10.1016/j.gloenvcha.2009.10.001

Young, O. R., F. Berkhout, G. C. Gallopin, M. A. Janssen, E. Ostrom, and S. van der Leeuw. 2006. The globalization of socio-ecological systems: an agenda for scientific research. Global Environmental Change 16(3):304-316. http://dx.doi. org/10.1016/j.gloenvcha.2006.03.004

Zeppel, H. 2012. Climate change and tourism in the Great Barrier Reef Marine Park. Current Issues in Tourism 15:287-292. http://dx.doi.org/10.1080/13683500.2011.556247 